Laporan Penelitian

\title{
Peran neutral endopeptidase terhadap inflamasi saluran napas atas pada penderita obstructive sleep apnea
}

\author{
Hatmansjah*, Marsetyawan Heparis Nur Ekandaru Soesatyo", \\ Bambang Hermani**, Indwiani Astuti*, Bambang Uji Djoko Rianto* \\ *Program Pascasarjana Fakultas Kedokteran Universitas Gadjah Mada \\ Yogyakarta \\ ${ }^{* *}$ Departemen Telinga Hidung Tenggorok - Bedah Kepala Leher \\ Fakultas Kedokteran Universitas Indonesia/Rumah Sakit Dr. Cipto Mangunkusumo \\ Jakarta
}

\begin{abstract}
ABSTRAK
Latar belakang: Obstructive sleep apnea (OSA) pada anak yang berhubungan dengan excessive daytime somnolance (EDS), gagal tumbuh, kelainan kardiovaskular, gagal napas, dan kematian, prevalensinya terus meningkat. Inflamasi berperan pada patogenesis penyakit tersebut. Tujuan: Mengetahui peran neutral endopetidase (NEP) terhadap inflamasi pada penderita OSA dan hubungannya dengan mediator inflamasi subtance $P$ (SP), interleukin-4 (IL-4), dan tumor necrosis factor $\alpha$ (TNF- $\alpha$ ). Metode: Penelitian potong lintang dilakukan pada pada 36 pasien hipertrofi tonsil dan adenoid selama Mei 2013-2015. Diagnosis OSA ditegakkan dengan polisomnografi, dan kadar NEP, SP, IL-4 dan TNF- $\alpha$ yang berasal dari tonsil maupun adenoid dengan imunohistokimia. Hasil: Terdapat 21 penderita OSA $(58,3 \%)$ dan 15 subjek tidak OSA $(41,7 \%)$, dari total 36 sampel. Dijumpai hubungan yang bermakna antara SP tonsil dan SP adenoid dengan OSA, serta IL-4 tonsil dengan OSA $(p<0,05)$. Walau kadar NEP tonsil dan NEP adenoid lebih sedikit pada OSA, serta IL-4 adenoid, TNF- $\alpha$ tonsil dan adenoid lebih besar pada OSA, perbedaan tersebut tidak bermakna $(\mathrm{P}>0,05)$. Dijumpai juga hubungan yang bermakna antara SP tonsil dengan IL-4 tonsil dan SP tonsil dengan TNF- $\alpha$ tonsil $(\mathrm{p}<0,05)$. Kesimpulan: Terdapat hubungan yang tidak bermakna antara NEP dan OSA, namun ditemukan hubungan yang bermakna antara SP dan IL-4 dengan OSA.
\end{abstract}

Kata kunci : Obstructive sleep apnea, neutral endopeptidase, substance P, interleukin-4

\section{ABSTRACT}

Background: The prevalence of obstructive sleep apnea (OSA) in children, which can lead to excessive daytime somnolance (EDS), failure to thrive, cardiovascular disorders and respiratory failure and death, continues to rise. Inflammation is associated with OSA. Purpose: To identify the role of neutral endopeptidase (NEP) to inflammation in obstructive sleep apnea (OSA), and its association to inflammatory mediator subtance P (SP), interleukin-4 (IL-4) and tumor necrosis factor- $\alpha$ (TNF- $\alpha$ ). Methods: A crosssectional study had been done to 36 adenotonsilar hypertrophy child patients with OSA during the period of time from May 2013-2015. OSA was diagnosed based on polisomnografi and the level of NEP, SP, IL-4 and TNF- $\alpha$ by imunohistochemistry. Results: We found 21 subjects had OSA (58.3\%) and 15 subjects did not have OSA (41.7\%), from total sample 36. There were significant associations between SP tonsil, SP adenoid and IL-4 tonsil with OSA ( $p<0.05)$. Although the number of NEP level in OSA was smaller than non OSA and IL-4 adenoid, TNF- $\alpha$ tonsil and TNF- $\alpha$ adenoid OSA were found greater than non OSA, but the difference between them were not significant ( $p>0.05$ ). Conclusion: This study did not found a significant correlation between NEP with OSA but there were significant correlations between SP and IL-4 with OSA.

Keywords: Obstructive sleep apnea, neutral endopeptidase, substance P, interleukin-4

Alamat Korespondensi: Hatmansjah, SMF THT RSUP Persahabatan, Jl. Persahabatan Raya No. 1, Jakarta,Email: hatmansjah@yahoo.com 


\section{PENDAHULUAN}

Obstructive sleep apnea (OSA) adalah suatu kondisi yang ditandai dengan kolaps saluran napas atas, baik menyeluruh maupun sebagian, terjadi berulang, yang terjadi selama tidur, sehingga mengakibatkan gangguan pertukaran gas dan gangguan tidur. ${ }^{1,2}$ OSA dapat terjadi pada semua kelompok umur dengan karakteristik yang berbeda. ${ }^{3}$ OSA pada anak dapat menyebabkan excessive daytime somnolance (EDS), gagal tumbuh, kelainan kardiovaskular, serta gagal napas, sampai kematian. ${ }^{3,4}$ Prevalensi OSA pada anak diperkirakan sebesar 2-3,5\%. Prevalensi ini mempunyai dua periode puncak yaitu periode puncak pertama terjadi pada usia 2-8 tahun, di mana pada periode ini terjadi pembesaran tonsil dan adenoid, serta periode puncak kedua yang terjadi pada usia pra-pubertas yang dikaitkan dengan peningkatan berat badan. ${ }^{5}$

Walaupun etiologi OSA masih belum pasti, namun inflamasi lokal maupun sistemik dapat dijumpai pada pasien OSA..$^{6-8}$ Getaran saluran napas atas akibat dengkur dan peningkatan upaya bernapas melawan obstruksi yang terjadi berulang-ulang dapat memicu timbulnya inflamasi lokal atau edema pada saluran napas atas. ${ }^{7}$ Keadaan tersebut telah dibuktikan pada hewan coba tikus, bahwa rangsang mekanik berupa getaran, serta kolaps, dan terbukanya kembali saluran napas atas yang terjadi berulang-ulang seperti pada OSA dapat menimbulkan inflamasi lokal, yang dibuktikan dengan ditemukannya TNF- $\alpha$, macrophage inflammatory protein (MIP)- 2 , dan IL- $\beta$ pada jaringan saluran napas atas hewan coba tersebut. ${ }^{9,10}$ Sebaliknya, inflamasi lokal pada saluran napas atas menyebabkan timbulnya gangguan refleks dan disfungsi otot dilator faring, sehingga lebih mudah terjadinya kolaps saluran napas atas. Selain itu, inflamasi juga dapat menyebabkan penyempitan saluran napas atas, yang secara bersamaan dapat menyebabkan terjadinya OSA. ${ }^{7}$

Pada anak, inflamasi juga dikaitkan dengan hipertrofi jaringan limfoid yang dapat bersifat sementara maupun permanen. ${ }^{8}$ Disproporsi pertumbuhan tonsil dan adenoid terutama terjadi pada anak dengan rinitis alergi, asma, saluran napas atas terpapar asap rokok, dan riwayat infeksi respiratory syncytial virus (RSV) yang dapat meningkatkan proliferasi jaringan limfoid saluran napas atas. ${ }^{11,12}$

Beberapa peneliti seperti Kim et $\mathrm{al}^{13}$ dan Tauman \& Gozal ${ }^{11}$ menemukan peningkatan kadar TNF- $\alpha$, IL-6, dan IL-1 $\alpha$ yang bermakna pada jaringan tonsil anak, yang terbukti OSA, dibanding tonsilitis berulang. Interleukin-4 (IL4) yang berasal dari T-helper 2 (Th2) dan sel mast, adalah sitokin yang merupakan kunci bagi perkembangan alergi. IL-4 merupakan stimulus utama produksi imunoglobulin E (IgE) oleh sel limfosit B serta diferensiasi dan proliferasi Th2 dari sel T. ${ }^{14,15}$ Penelitian sebelumnya telah melaporkan pada pasien OSA anak terdapat prevalensi yang tinggi untuk alergi dan terpapar virus saluran napas atas. ${ }^{14}$

Zakkar et a ${ }^{16}$ menemukan bahwa neutral edopeptidase (NEP) yang membelah dan menginaktivasi mediator-mediator inflamasi neuropetida dan peptida seperti SP, vasoactive intestinal peptide (VIP) dan bradikinin pada mukosa saluran napas atas, jumlahnya pada epitel uvula pasien OSA menurun dibandingkan pada kadaver yang diketahui tidak OSA. Goldbart et $\mathrm{al}^{8}$ mendapatkan ekspresi SP yang lebih tinggi secara bermakna pada pasien hipertrofi tonsil dan adenoid yang terbukti OSA, dibanding tanpa OSA. Keadaan ini akan meningkatkan inflamasi saluran napas atas yang dipicu oleh mediator-mediator inflamasi tersebut.

Pentingnya NEP pada proses inflamasi telah banyak dilaporkan. Umeno et $\mathrm{a}^{17}$ memperlihatkan bahwa inhibisi terhadap NEP dapat memperbesar inflamasi neurogenik pada hewan coba tikus. Lily et al ${ }^{18}$ membuktikan bahwa pemaparan berulang antigen tolueane dysocyanate dan asap rokok pada hewan coba guinea pig dapat menyebabkan kadar dan aktivitas NEP menurun, mediator-mediator inflamasi terutama SP menurun, konsentrasi SP 
meningkat dan keadaan ini akan meningkatkan efek kontraktil SP yang pada akhirnya meningkatkan inflamasi disertai episode sumbatan saluran napas atas. Sebaliknya pemberian recombinant human neutral endopeptidase (rhNEP) dapat memperlemah inflamasi. ${ }^{19}$

Penelitian Zakkar ${ }^{16}$ menemukan penurunan kadar NEP pada pasien OSA dengan membandingkan terhadap kadaver yang diketahui tidak OSA. Namun, perlu dibuktikan apakah ada hubungan antara penurunan kadar NEP dengan peningkatan jumlah mediator inflamasi sitokin seperti IL-4 maupun TNF- $\alpha$.

Tujuan penelitian ini adalah untuk mengetahui peran neutral endopetidase terhadap inflamasi pada penderita OSA dan hubungannya dengan mediator inflamasi subtance $P$ (SP), interleukin-4 (IL-4), dan tumor necrosis factor- $\alpha$ (TNF- $\alpha$ ).

\section{METODE}

Penelitian ini menggunakan desain potong lintang dan dilakukan di Rumah Sakit Persahabatan, Rumah Sakit PGI Cikini, Rumah Sakit Sentra Medika, dan Laboratorium Histologi Fakultas Kedokteran Universitas Indonesia. Populasi sampel penelitian adalah semua pasien anak dengan keluhan dengkur. Kriteria inklusi untuk kelompok OSA dan tidak OSA adalah pasien anak umur 2-18 tahun dengan keluhan dengkur, serta pada pemeriksaan fisik ditemukan hipertrofi tonsil dan adenoid. Setiap subjek penelitian mendapat pemeriksaan PSG untuk mengelompokkan subjek ke dalam kelompok OSA atau tidak. Kemudian, subjek diminta kesediaannya untuk dilakukan tonsiloadenoidektomi (TA), bagi yang datang ke RS Persahabatan, atau RS PGI Cikini, atau RS Sentra Medika. Kriteria esklusi untuk kelompok OSA dan kelompok tidak OSA pada penelitian ini adalah menolak untuk dilakukan operasi TA, dan/atau menderita asma, dan/atau merokok atau baru berhenti merokok kurang dari satu tahun.
Penelitian dimulai dengan melakukan penapisan pada pasien anak yang mendengkur dan dicurigai menderita OSA dengan anamnesis atau aloanamnesis. Selanjutnya dilakukan pemeriksaan fisik serta pemeriksaan PSG menggunakan Alice PDx portable monitoring devise, dan kemudian dilakukan TA. Jaringan tonsil dan adenoid pada pasien OSA dan tidak OSA yang didapat dari operasi tersebut dibawa ke laboratorium Patologi Anatomi RSUP Persahabatan untuk pemeriksaan histopatologi dan ke laboratorium Histologi FK UI untuk pemeriksaan imunohistokimia (IHK). Tidak ada kriteria baku untuk mengklasifikasikan peradangan ke dalam kategori ringan, sedang atau berat/keras. Tonsil dan adenoid hanya merupakan kumpulan jaringan limfoid yang dilapisi oleh epitel. Berdasarkan hal tersebut maka dokter spesialis patologi anatomi di RS Persahabatan mengklasifikasikan (khusus untuk penelitian ini) peradangan keras bila dijumpai infiltrasi sel radang yang padat pada permukaan epitel maupun daerah sub-epitel. Peradangan ringan bila dijumpai infiltrasi sel radang yang jarang. Peradangan sedang bila dijumpai infiltrasi sel radang di antara padat dan jarang pada permukaan epitel maupun daerah sub-epitel.

Penelitian ini telah dikaji dan disetujui oleh Komisi Etik dan Penelitian RSUP Persahabatan dan mendapat keterangan lolos uji etik No.03/KEPK-RSUPP/IV/2013. Formulir pengumpulan data seluruhnya diisi oleh orang tua pasien dengan mayoritas pendidikan terakhir sekolah lanjutan atas, diikuti dengan perguruan tinggi, dan sekolah lanjutan pertama. Orang tua pasien yang putraputrinya diikutsertakan pada penelitian ini telah diberi penjelasan dan menandatangani lembar informed consent penelitian.

\section{HASIL}

Sejak Mei 2013-2015, kami berhasil mengumpulkan 36 sampel dari total sampel sebanyak 52 pasien, dengan keluhan dengkur 
dan pada pemeriksaan fisik serta radiologi dijumpai hipertrofi tonsil dan adenoid, yang memenuhi kriteria penelitian. Ukuran tonsil seluruhnya $\geq \mathrm{T} 3-\mathrm{T} 3$ sesuai kriteria Brodsky dan hipertrofi adenoid ditetapkan berdasarkan ekspertise dokter spesialis Radiologi pada foto polos sinus para nasal posisi lateral. Didapatkan jumlah sampel jaringan tonsil sebanyak 36 dan jumlah sampel jaringan adenoid sebanyak 35 .

Terdapat 21 penderita OSA $(58,3 \%)$ dan 15 subjek tidak OSA $(41,7 \%)$, dari total 36 sampel. Proporsi jenis kelamin pada kelompok OSA (laki-laki 71,4\%, perempuan $28,6 \%$ ) hampir sama dengan kelompok tidak OSA (laki-laki 66,7\%, perempuan 33\%). Kelompok anak-anak (5-11 tahun) lebih banyak dijumpai pada kelompok OSA $(90,5 \%)$ dibandingkan dengan kelompok tidak OSA $(66,3 \%)$. Sebaliknya, usia remaja awal (12-16 tahun) lebih banyak dijumpai pada kelompok tidak OSA (33,3\%) dibanding kelompok OSA $(9,5 \%)$. Sebagian besar kelompok OSA $(28,6 \%)$ mengalami kekurangan berat badan tingkat berat, sedangkan sebagian besar kelompok tidak OSA $(46,7 \%)$ memiliki status gizi yang normal.

Pada kelompok tidak OSA, diketahui rerata umur sebesar 8,73, sedangkan umur kelompok
OSA dengan rerata sebesar 7,81. Rerata berat badan kelompok OSA sebesar 32,71 kg, sedangkan berat badan kelompok tidak OSA, dengan rerata sebesar $28,87 \mathrm{~kg}$. Rerata tinggi badan pada kelompok OSA sebesar 125,52 cm, sedangkan tinggi badan kelompok tidak OSA, dengan rerata sebesar $129,27 \mathrm{~cm}$. Rerata IMT pada kelompok OSA sebesar $21,18 \mathrm{~kg} / \mathrm{m}^{2}$, sedangkan pada kelompok tidak OSA 17,81 $\mathrm{kg} / \mathrm{m}^{2}$. Rerata lingkar leher kelompok OSA sebesar $30,86 \mathrm{~cm}$, sedangkan rerata lingkar leher kelompok tidak OSA sebesar 30,07 cm (tabel 2).

Dari hasil pemeriksaan histopatologi tonsil diketahui bahwa inflamasi didominasi oleh peradangan ringan dan sedang. Peradangan keras pada kelompok OSA hanya $4,8 \%$, bahkan lebih sedikit dari kelompok tidak OSA yaitu sebanyak 13,3\%. Hasil yang normal diperlihatkan pada histopatologi adenoid yaitu $4,8 \%$ pada kelompok OSA dan $7,1 \%$ pada kelompok tidak OSA (tabel 3).

Dijumpai rerata kadar SP, IL-4 dan TNF- $\alpha$ (tonsil maupun adenoid) pada kelompok OSA lebih tinggi dibanding kelompok tidak OSA. Namun sebaliknya jumlah rerata NEP tonsil maupun adenoid, pada kelompok OSA lebih rendah dibanding kelompok tidak OSA (tabel 4).

Tabel 1. Karakteristik sampel penelitian

\begin{tabular}{|c|c|c|c|c|}
\hline Variabel & OSA & $\%$ & Tidak OSA & $\%$ \\
\hline Sampel penelitian & 21 & 58,3 & 15 & 41,7 \\
\hline \multicolumn{5}{|l|}{ Jenis kelamin } \\
\hline Laki-laki & 15 & 71,4 & 10 & 66,7 \\
\hline Perempuan & 6 & 28,6 & 5 & 33,3 \\
\hline \multicolumn{5}{|l|}{ Umur } \\
\hline Anak-anak (5-11 tahun) & 19 & 90,5 & 10 & 66,3 \\
\hline Remaja awal (12-16 tahun) & 2 & 9,5 & 5 & 33,3 \\
\hline \multicolumn{5}{|l|}{ Status Gizi } \\
\hline Kekurangan berat badan tingkat berat & 5 & 23,8 & 6 & 40,0 \\
\hline Kekurangan berat badan tingkat ringan & 6 & 28,6 & 2 & 13,3 \\
\hline Normal & 5 & 23,8 & 7 & 46,7 \\
\hline Kelebihan berat badan tingkat ringan & 2 & 9,5 & 0 & 0 \\
\hline Kelebihan berat badan tingkat berat & 3 & 14,3 & 0 & 0 \\
\hline
\end{tabular}


Tabel 2. Karakteristik sampel penelitian

\begin{tabular}{lcccc}
\hline \multicolumn{1}{c}{ Variabel } & \multicolumn{2}{c}{ OSA } & \multicolumn{2}{c}{ Tidak OSA } \\
& Rerata & Simpang baku & Rerata & Simpang baku \\
\hline Umur & 7,81 & 2,23 & 8,73 & 3,34 \\
Berat badan & 32,71 & 13,30 & 28,87 & 11,79 \\
Tinggi badan & 125,52 & 14,88 & 129,27 & 20,25 \\
IMT & 21,18 & 7,32 & 17,81 & 2,86 \\
Lingkar leher & 30,86 & 3,24 & 30,07 & 3,77 \\
\hline
\end{tabular}

Tabel 3. Histopatologi tonsil dan adenoid

\begin{tabular}{lrrrr}
\hline \multicolumn{1}{c}{ Variabel } & OSA & $\mathbf{\%}$ & Tidak OSA & \% \\
\hline Histopatologi Tonsil & & & & 0 \\
Normal & 0 & 0 & 0 & 26,7 \\
Ringan & 7 & 33,3 & 4 & 60,0 \\
Sedang & 13 & 61,9 & 9 & 13,3 \\
Keras & 1 & 4,8 & 2 & 7,1 \\
Histopatologi Adenoid & & & \\
Normal & 1 & & 1 & 7,1 \\
Ringan & 2 & 4,8 & 1 & 64,4 \\
Sedang & 11 & 9,5 & 9 & 21,4 \\
Keras & 7 & 52,4 & 3 & \\
\hline
\end{tabular}

Tabel 4. Karakteristik sampel penilitian berdasarkan NEP, SP, IL-4 dan TNF- $\alpha$

\begin{tabular}{lccrc}
\hline \multicolumn{1}{c}{ Variabel } & \multicolumn{2}{c}{ OSA } & \multicolumn{2}{c}{ Tidak OSA } \\
& Rerata & Simpang baku & Rerata & Simpang baku \\
\hline NEP tonsil & 1,19 & 0,98 & 1,53 & 1,41 \\
SP tonsil & 21,86 & 9,64 & 12,67 & 7,19 \\
IL-4 tonsil & 2,62 & 2,06 & 1,20 & 1,37 \\
TNF- $\alpha$ tonsil & 3,52 & 2,36 & 3,00 & 3,19 \\
NEP adenoid & 2,43 & 3,06 & 3,47 & 4,79 \\
SP adenoid & 28,43 & 14,53 & 13,73 & 13,06 \\
IL-4 adenoid & 3,33 & 6,11 & 2,80 & 3,61 \\
TNF- $\alpha$ adenoid & 3,24 & 3,87 & 1,40 & 1,24 \\
\hline
\end{tabular}

Hubungan antara NEP, SP, IL-4, dan TNF- $\alpha$ tonsil maupun adenoid dengan OSA dapat dilihat pada tabel 5. Hubungan yang bermakna hanya dijumpai pada IL-4 tonsil dengan OSA $(p=0,038)$ dengan $\mathrm{OR}=1,7$, dan $\mathrm{SP}$ tonsil dengan $\operatorname{OSA}(\mathrm{p}=0,022)$ dengan $\mathrm{OR}=1,14$, serta SP adenoid dengan OSA $(p=0,012)$ dengan OR 1,1.

Dijumpai hubungan yang bermakna antara SP yang berasal dari tonsil dengan IL-4 yang juga berasal dari tonsil $(\mathrm{p}=0,048)$, serta SP yang berasal dari tonsil dengan TNF- $\alpha$ yang berasal dari tonsil $(p=0,029)$.

Gambar 1 dan gambar 2 memperlihatkan grafik yang menunjukkan adanya hubungan yang positif antara SP tonsil dan IL-4 tonsil, serta antara SP tonsil dengan TNF- $\alpha$ tonsil, dan hubungan tersebut signifikan. Terlihat garis regresi naik ke arah kanan, cukup terjal. Korelasi semakin kuat jika kenaikan garis regresi semakin terjal. 
Tabel 5. Hubungan antara variabel bebas yang diteliti dengan OSA

\begin{tabular}{|c|c|c|}
\hline Variabel bebas & P-value & Odds Ratio (OR) \\
\hline NEP tonsil & 0,387 & 1,3 \\
\hline SP tonsil & 0,022 & 1,14 \\
\hline IL-4 tonsil & 0,038 & 1,7 \\
\hline TNF- $\alpha$ tonsil & 0,562 & 0,93 \\
\hline NEP adenoid & 0,422 & 1,1 \\
\hline SP adenoid & 0,012 & 1,1 \\
\hline IL-4 adenoid & 0,948 & 1,02 \\
\hline TNF- $\alpha$ & 0,116 & 0,72 \\
\hline
\end{tabular}

Tabel 6. Hasil dari analisis bivariat antara masing-masing variabel bebas

\begin{tabular}{|c|c|c|}
\hline Variabel 1 & Variabel 2 & P Value \\
\hline \multirow[t]{3}{*}{ NEP tonsil } & TNF- $\alpha$ tonsil & 0,207 \\
\hline & IL-4 tonsil & 0,225 \\
\hline & SP tonsil & 0,658 \\
\hline \multirow[t]{2}{*}{ SP tonsil } & TNF- $\alpha$ tonsil & 0,029 \\
\hline & IL-4 tonsil & 0,048 \\
\hline \multirow[t]{3}{*}{ NEP adenoid } & TNF- $\alpha$ adenoid & 0,397 \\
\hline & IL-4 adenoid & 0,200 \\
\hline & SP adenoid & 0,579 \\
\hline \multirow[t]{2}{*}{ SP adenoid } & TNF- $\alpha$ adenoid & 0,759 \\
\hline & IL-4 adenoid & 0,298 \\
\hline
\end{tabular}

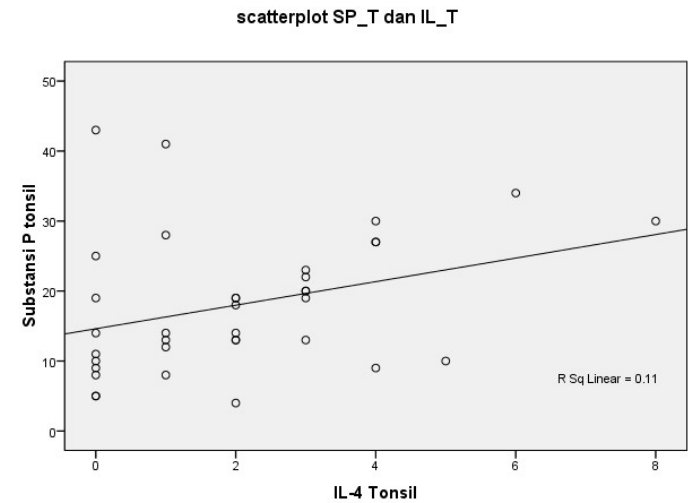

Gambar 1. Diagram scatter SP tonsil dengan IL-4 tonsil

\section{DISKUSI}

Pada orang dewasa diagnosis OSA ditegakkan bila dijumpai $\mathrm{AHI} \geq 15$ tanpa memperhatikan ada atau tidaknya gejala, atau $\mathrm{AHI} \geq 5$ disertai dengan gejala klinis. Dengan alasan pada anak OSA harus ditangani lebih dini, maka para ahli menggunakan batasan $\mathrm{AHI} \geq 3$ atau $\mathrm{AHI} \geq 1$ untuk menegakkan diagnosis OSA. ${ }^{5}$ Pada penelitian ini, bila

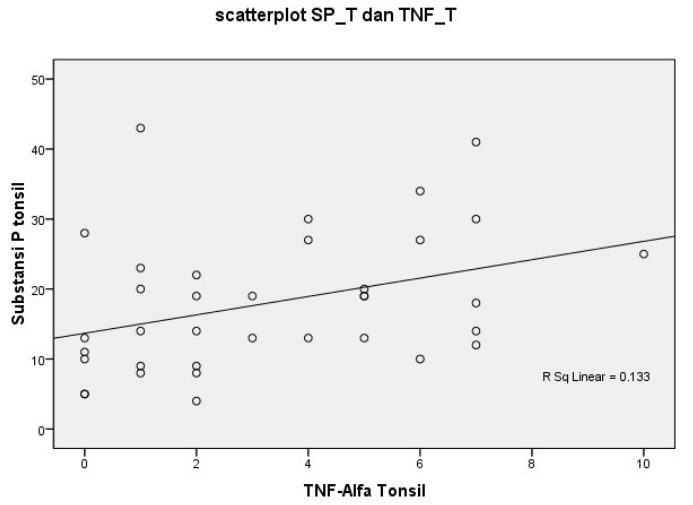

Gambar 2. Diagram scatter SP tonsil dengan TNF- $\alpha$ tonsil

diagnosis OSA ditegakkan atas batasan AHI $\geq 1$, maka didapat prevalensi OSA sebesar $77,8 \%$ dan bila digunakan batasan $\mathrm{AHI} \geq 3$ maka didapat prevalensi sebesar 58,3\%. Hasil penelitian ini sesuai dengan penelitian terdahulu, yang mendapatkan angka $30-60 \% .{ }^{20}$ Diagnosis OSA ditegakkan berdasarkan AHI $\geq 3$, sehingga didapat kelompok OSA sebanyak $21(58,3 \%)$ dan kelompok tidak OSA sebanyak $15(41,7 \%)$. 
Pada penelitian ini didapat sampel dengan jumlah 15 laki-laki $(71,4 \%)$ dan 6 perempuan $(28,6 \%)$. Berdasarkan berbagai literatur, tidak terdapat perbedaan proporsi jenis kelamin pada anak yang menderita OSA. ${ }^{5}$ Akan tetapi, pada penelitian ini didapati prevalensi anak laki-laki lebih tinggi dari perempuan. Hal ini mungkin dapat disebabkan oleh sedikitnya jumlah sampel.

Umur bukan merupakan faktor risiko OSA, baik pada anak maupun dewasa. ${ }^{5} \mathrm{Hal}$ ini juga terlihat pada penelitian ini yang mendapatkan bahwa tidak ada perbedaan yang bermakna antara umur dengan OSA. Sebanyak 90,5\% OSA terjadi pada usia anak (5-11 tahun). Terdapat dua periode puncak prevalensi OSA yaitu pada anak yaitu usia 2-8 tahun yang dikaitkan dengan hipertrofi tonsil dan adenoid, dan usia remaja yang dikaitkan dengan pertambahan berat badan. ${ }^{5}$

Pada anak yang menderita OSA, obesitas bukan merupakan faktor risiko yang penting untuk terjadinya OSA. Faktor risiko yang penting adalah hipertrofi tonsil dan adenoid. Sebagian besar anak obesitas dengan OSA mempunyai hipertrofi tonsil dan adenoid. ${ }^{5}$ Pada penelitian ini, terbukti OSA justru lebih banyak ditemukan pada anak yang kurus (kekurangan berat badan tingkat berat dan ringan) yaitu sebesar 52,4\%, dibanding anak gemuk (kelebihan berat badan tingkat ringan dan berat) sebanyak $23,8 \%$.

Patologi infiltrasi sel-sel radang pada permukaan epitel tonsil digunakan sebagai kriteria adanya inflamasi. Tidak ada kriteria baku untuk mengklasifikasikan sebagai peradangan ringan, sedang atau berat/keras. ${ }^{21}$

Pada penelitian ini masing-masing ditemukan satu sampel adenoid dari kelompok OSA $(4,8 \%)$ dan tidak OSA $(7,1 \%)$, yang normal. Keadaan ini dapat memungkinkan, karena pengobatan yang diberikan sebelum operasi dapat menghilangkan peradangan yang disebabkan oleh infeksi. Keadaan ini juga dapat menerangkan mengapa peradangan keras pada tonsil justru lebih banyak ditemukan pada tidak OSA (13,3\%) dibanding kelompok OSA $(4,8 \%)$. Keadaan yang tidak kosisten ini juga ditemukan oleh Berger et $\mathrm{al}^{22}$ yang mendapatkan tidak ada perbedaan yang bermakna pada inflamasi uvula dan palatum mole antara pasien OSA ringan, sedang dan berat dengan kadaver yang diketahui tidak OSA.

Dijumpai hubungan yang bermakna antara SP (tonsil dan adenoid) dan IL-4 (tonsil) dengan OSA. Selain itu, jumlah IL-4 adenoid pada pasien OSA ditemukan lebih besar dibanding pasien tidak OSA, walaupun secara statistik tidak bermakna. Hal ini menunjukkan bahwa proses inflamasi, baik itu inflamasi neurogenik maupun inflamasi imunogenik berperan pada kejadian OSA.

Stimulasi saraf sensoris apapun penyebabnya akan menyebabkan terjadinya pelepasan mediator inflamasi neurogenik seperti neuropeptida SP, neurokinin A (NKA) dan calcitonin gene related peptide (CGRP). Di samping menyebabkan peningkatan permeabilitas kapiler, kontraksi otot polos serta peningkatan sekresi kelenjar, mediatormediator inflamasi neurogenik ini dapat juga memicu degranulasi sel mast sehingga terjadi pelepasan mediator-mediator inflamasi imunogenik seperti histamin, prostaglandin, leukotrine, faktor khemotaktik dan sitokin. ${ }^{23}$ Mediator inflamasi imunogenik tersebut menghasilkan respon inflamasi, serta dapat menstimulasi serabut saraf $C$ untuk melepas neuropeptida SP, NKA dan CGRP. ${ }^{23,24}$ Hipoksia yang terjadi akibat kolaps saluran napas atas pada pasien OSA dapat juga menginduksi keberadaan mediator inflamasi sitokin terutama TNF- $\alpha$ dan IL-6. ${ }^{25}$

Pada penelitian ini juga didapat hubungan yang bermakna antara SP tonsil yang merupakan mediator inflamasi neurogenik, dengan IL-4 tonsil yang merupakan mediator inflamasi imunogenik. Hubungan yang bermakna antara SP tonsil dengan TNF- $\alpha$ tonsil, yang merupakan mediator inflamasi 
imunogenik. Hubungan tersebut mempunyai korelasi positif yang artinya setiap kenaikan jumlah SP akan diikuti dengan kenaikan IL-4 dan TNF- $\alpha$.

Penelitian ini menemukan hubungan yang tidak bermakna antara NEP dengan OSA. Akan tetapi, ditemukan hubungan yang bermakna antara SP dengan OSA dan IL-4 yang merupakan kunci dari inflamasi alergi dengan OSA. Selain itu, ditemukan juga hubungan antara SP (inflamasi neurogenik) dengan IL-4 dan TNF- $\alpha$ (inflamasi imunogenik).

\section{DAFTAR PUSTAKA}

1. Lam JCM, Sharma S, Lam B. Obstructive sleep apnea: Definitions, epidemiology \& natural history. Indian J Med Res. 2010; 131:165-170.

2. Guilleminault C, Takaoka S. Sign and symptom of obstructive sleep apnea and upper airway resistance syndrome in: Friedman M, editors. 2009. Sleep apnea and snoring, surgical-non surgical therapy. Chicago. Saunders Elsevier; 2009. Chapter 2. p. 3-10

3. Schehter MS. Technical report: Diagnosis and management of childhood obstructive sleep apnea syndrome. Pediarics, 2002; 109: 1-20.

4. Redline S, Tishler VP, Strohl K. The genetic of OSHAS in: Peck IA, editors 2002. Sleep Apnea. Pathogenesis, diagnosis and treatment. Newyork. Marcel Decker Inc; Chapter 8. p. 235-264.

5. Chang SJ, Chae KY. Obstructive sleep apnea syndrome in children; Epidemiology, pathophysiology, diagnosis and sequelae. Korean J Pediatr. 2010; 53 (10): 863-871.

6. Sabato R, Guido P, Salerno S, Resta O, Spanevello A, Barbaro MPF. 2006. Airway imflamation in patients affected by obstructive sleep apnea. Monaldi Arch Chest Dis. 2006; 65 (2): 102-105.
7. Hatipoglu U, Rubinstein I. Imflamation and obstructive sleep apnea syndrome pathogenesis: A working hypothesis. Respiration. 2003; 70 (6): 665-671.

8. Goldbart AT, Marger E, Veling MC, Goldman JL, Gozal K, Serpero LD. Neutrophins and tonsilar hypertrophy in children with obstructive sleep apnea. Pediatric Research.2007; 62(4): 489-494.

9. Almendros I, Acerbi I, Puig F, Montserat JM, Nevajas D, Farre R. Upper airway inflammation triggered by vibration in rat model of snoring. Sleep, 2007; 30(2): 225 227.

10. Almendros I, Carreras A, Ramirez J, Montserrat M, Farre R. Upper airway collapse and reopening induce imflamation in a sleep apnea model. Eur Respir J. 2008; 32: 399-404.

11. Tauman R, Gozal D. Obstructive Sleep Apnea in Children. Expert Rev Resp Med. 2011; 5(3): 425-440.

12. Gozal D, Bhattacharje R, Goldman JL, Gozal KL. Substance P and Neurokinin 1 Receptors as Potential Therapeutic Targets in Children with OSA. Chest. 2014; 145(5) : 1039-1045.

13. Kim J, Bhattacharjee R, Dayyat E, Snow AB, Gozal LK, Goldman JL. Increased cellular proliferation and inflammatory $\mathrm{S} \mathrm{K}$, Chan IH. Inflammatory cytokines and childhood obstructive sleep apnea. Ann Acad Med Singapore 2008; 37(8): 649-654.

14. Steinke JW, Borish L. Review Th2 cytokines and asthma, IL-4: its role in the pathogenesis of asthma, and targeting it for asthma treatment with IL-4 receptor antagonist. Respir Res. 2001; 2: 66-70.

15. Baratawidjaja GK, Rengganis I. Sitokin. In: Baratawidjaja editor. Imunologi Dasar edisi ke 9. Jakarta; Balai Penerbit FKUI; Bab 9:217-256.

16. Zakkar M, Sekosan M, Wenig B, Olopade $\mathrm{CO}$, Rubestein I. Immunoreactive neutral endopeptidase is decreased in uvula epithelium of patiens with obstructive sleep apnea. Ann Otol Laryngol 1997; 106: 474477. 
17. Umeno E, Nadel JA, Huang TH, McDonal DM. Inhibition of neutral endopeptidase potentiates neurogenic inflamtion in the rat trachea. J Appl Physiol. 1989; 66(6): 26472652.

18. Lily CM, Kobzik L, Hall AE, Drezen JM. Effects of chronic airway inflammation on the activity and enzymatic inactivation of neuropeptides in guinea pig lungs. J Clin Invest. 1994; 93: 2667-2674.

19. Kirkwood KS, Bunnett NW, Maa J, Castagliolo I, Liu B, Gerard N, et al. Deletion of neutral endopeptidase exacerbates intestinal inflammation induce by clostridium difficile toxin A. Am J Physiol Gastrointest liver Physiol. 2001; 281(2): 544-551.

20. Katz ES, D'Ambrosio CM. Pathophysiology of pediatric obstructive sleep apnea. Proc Am Thorac Soc. 2007; 5: 253-162.
21. Ugras S, Kuthulan A. Chronic tonsillitis can be diagnosis with histophatolpgical findings. Eur J Gen Med. 2008; 5(2): 95-130.

22. Berger G, Gilbey P, Hammel I, Ophir D. Histopathology of the uvula and soft palate in patients with mild, moderate and severe sleep apnea. The Laryngoscope. 2002; 112: 357-363.

23. Megg JW. Neurogenic swithicing: A hypothesis for a mechanism for shifting the site of inflammation in allergy and chemical sensitivity. Environ Health Perspect. 1995; 103:54-56.

24. Dokic TD, Sumrak TD. Airways neurogenic inflammation. Med Data Rev. 2010; 2(4):333340.

25. Li AM, Lam HS, Chan MH, So HK, Nq S $\mathrm{K}$, Chan IH. Inflammatory cytokines and childhood obstructive sleep apnea. Ann Acad Med Singapore 2008; 37(8): 649-654. 